\title{
Perception of farm women of Tinsukia district of Assam towards use of improved serrated sickle for drudgery reduction
}

\author{
Mrinmoy Chetia*, Rupak Kr. Nath and Amal Ch. Sarmah \\ Krishi Vigyan Kendra (A.A.U.), Tinsukia (Assam) India
}

\section{ARITCLE INFO}

Received : 10.05 .2018

Revised : 08.09 .2018

Accepted : 22.09.2018

KEY WORDS :

Drudgery, Farm women, Improved sickle

Corresponding author: mrinmoysworld@gmail.com

\begin{abstract}
Agriculture is an important unorganized sector where majority of the women labour force is engaged either in their own field or in the fields of other farmers. Tinsukia is the East most district of Assam and the women of the farming community of the district mainly perform the activities like transplanting, weeding, harvesting, post harvest handling etc. The perception of farm women of Tinsukia district of Assam on efficiency of drudgery-reducing improved serrated sickle was studied and also SWOT analysis was done among 60 farm women selected through purposive random sampling method. It is observed that largest percentage of farm women are satisfied that the shape of the sickle can reduce physical injury during harvesting, time and energy saving, good grip and mostly that this is a women friendly tool. This analysis indicates that use of serrated sickle by farmwomen for harvesting of different crops could be a useful implement and found reduction in drudgery of farmwomen with increased output like harvesting of various crops, time saving, more income per unit of time and not require the sharpening of cutting edge frequently.
\end{abstract}

How to view point the article : Chetia, Mrinmoy, Nath, Rupak $\mathrm{Kr}$. and Sarmah, Amal Ch. (2018). Perception of farm women of Tinsukia district of Assam towards use of improved serrated sickle for drudgery reduction. Internat. J. Plant Protec., 11(2) : 158-160, DOI : 10.15740/ HAS/IJPP/11.2/158-160, Copyright@ 2018: Hind Agri-Horticultural Society. 